\title{
Import Network Pattern, Innovation Input and Output of European Union: A
}

\section{Research Based on Social Network}

\author{
Ruitian Wang*, Yan Wu \\ School of Economics and Business Administration, Central China Normal University, Luoyu Road, Wuhan \\ City, P. R. China \\ 429851374@qq.com,275212306@qq.com
}

Keywords: Import Trade Network, Innovation Input, Innovation Output

\begin{abstract}
Technology spillover through international trade is an important form of technology spillover. Using trade data of UNCOMTRADE to establish international trade relations between the EU member states in 2009-2015, this paper calculates the centrality and structural hole index of the import trade network of the EU member states using UCINET6.0 as a tool, in the social network analysis method. On this basis, the panel data model is constructed, and the moderating effects of centrality and structural holes on innovation output are taken into account. The results show that the centrality and structural holes of the import trade network of the EU members do not directly affect the innovation output, but play a positive moderating role in the function of innovation input on the innovation output.
\end{abstract}

\section{INTRODUCTION}

From the classical trade theory, new classical trade theory, new trade theory and the new classical international trade theory, when relates to develop-ment of international trade theory, the relationship between technological innovation and international trade is an unavoidable topic. Because of non-competition and partial non-exclusiveness, it is possible for international trade to induce technology spillover. Under the open economy, the economic growth of a country benefits from the innovation input of its own country, meanwhile one country's innovation activities can be spread indirectly to other countries through import trade (Keller, Wolfgang, 2002). The earliest explanations of technology spill-over through international trade are mainly the theory of contagion (Findlay, 1978) and the explana-tion from the perspective of externality (Arrow, 1962). The new growth theory, represented by Romer (1986) and Lucas (1988), emphasizes the positive effect of technology spillover through international trade on technological innovation. Grossman \& Helpman (1989) first study the rela-tionship between technological change and economic growth in the open economy by the framework of general equilibrium. From then on, many scholars have joined the study of mechanism and conditions of technology spillover effects of import trade on the basis of the research of Grossman \& Helpman (1989).

In the aspect of empirical research on technology spillover effects of import trade, based on "innovation driven" model, Coe \& Helpman (1995) has been built the $\mathrm{CH}$ model, for the first time to calculate the effect of import country's R\&D on the TFP from the perspective of evidence. After this, many research is mainly to improve the $\mathrm{CH}$ model, and the main features are as follows: on the one hand, the perfection of the variables, Coe, Helpman \& Haffmaister (1997) took the variable "secondary education" into account to revise the $\mathrm{CH}$ model; and Sjoholm and Fredrik (1996) use the patent citation as an important indicator to modify the $\mathrm{CH}$ model; and Engelbrecht and Hans-Jeurgen (1997) added in human capital variable into the model. On the other hand, from the total amount of research to industry analysis. Keller and Wolfgang (2002) divides R\&D into the domestic industry, other domestic industries, foreign trade and other foreign countries. Schiff, M. Yanling, W. and Olarreaga, M. (2002) examined the technology spillover effects of international trade between South and North countries and South-South countries from an industrial perspective.

The traditional analysis of trade effect of innovation output through international trade have adopted econometric method using attribute data, ignoring the analysis of relational data, so this paper employees the social network analysis method, with the research object defined in the variable trade relations, taking the use of UCINET6.0 as the analysis tool to calculate the centrality and structural holes of import trade network of EU Member States and use EVIEWS6.0 as the analysis tool, based on panel data from 2009 to 2015 to study the influence of the EU member countries import pattern on technological innovation of one country, and to discuss the role of import trade structure in technological innovation.

\section{THEORY AND HYPOTHESIS}

\subsection{Theoretical Basis}

Despite the existence of different voices, the technology spillover of import trade has reached a broad consensus. Therefore, this study takes the technology spillover through import trade as the basic theoretical presupposition. In SCP paradigm of the Harvard School, there is a one-way causal relationship between the structure, behavior and performance under the unified noumenon, although the Chicago school, New Industrial Organization theory and New Institutional school has modified or improved the SCP paradigm, but as the 
kernel of paradigm of the SCP, namely "structure influence behavior, and behavior influence performance” is still retained. This study attempts to combine the technology spillover effect through import trade with the SCP paradigm, and study the impact of import trade structure on innovation output under different noumenon. The idea of this study is: innovation input is an obvious key variable of innovation output, because of the technology spillover, the network structure of import trade will affect the function of innovation input on innovation output, that is to say, the import trade pattern of the network does not directly affect the innovation output, but plays a regulatory role in the function of innovation input on innovation output. This constitutes the theoretical basis of this study, and also formed the basic assumptions of this paper. This study uses social network which springs up in the sociological analysis to study the import trade structure among members of the European Union through the route of the relationship between the individual network.

\subsection{Key Assumptions}

\subsubsection{Centrality and Technology Spillover}

Within the European Union, what kind of power the member states have in the whole import trade network, or what kind of central position they are, is the first problem that should be faced when analyzing the import trade pattern within the EU. Social network analysis usually uses the centrality to represent the degree of the individual in the center, called centrality index. Centrality consists of degree centrality, betweenness centrality, and closeness centrality. This study uses relative degree centrality to measure the centrality of a country. The degree centrality is a portrait of the local center node index, strong ties between the nodes and the network measure actors in their own ability to integrate resources, trading ability and communication ability, without considering whether to control others. A point of the center and the degree is directly connected to the other points. Because this paper relates to network as a weighted network, so the degree of center of point A is aggregated of out-degree and in-degree, and the weight is the standard value of trade.

The degree centrality of social network depict country location in the network. On the one hand, one country locating in the heart of the national network has a higher status and power, can integrate the cyber source from a broader and deeper level, and can enhance a country's ability to obtain external resources (Zhiyong Zhang, Yi Liu, En Xie, 2007), which is conducive to a country's innovation output; On the other hand, if one country is located in the heart of the national network, there will be more and more countries are willing to establish trade relations with the country, which can enhance the power of price negotiation (Gnyawalid, Madhavan, 2001), then, to enhance the innovation output.

To this end, the following assumptions are proposed:

Hypothesis 1: import network centrality does not directly affect the output of innovation;

Hypothesis 2: import trade network centrality plays a positive moderating role in the impact of innovation input on innovation output.

\subsubsection{Structural Holes and Technology Spillover}

The structural hole theory originated in sociology research of Ronald Burt in 1992, which refers to some nodes which have a direct contact with other nodes in social networks, but have not direct contact with other nodes, so the whole network appears a kind of "empty" structure (Burt, 1992).

The structure hole represents a special structure formed by the relationship between at least three actors. The structure hole constitutes a kind of social capital because this structure may bring benefits (Granovetter, 1973). That is to say, to occupy structural holes has the vital significance to the occupants (Jun Liu, 2016). The more one country occupied structural holes in trade network, the more one country occupies more important position in trade network, and the more competitive in trade activities (Zhenfu Li, Yu Miao, Jing Chen, 2017).

To this end, this study proposes the following hypothesis:

Hypothesis 3: structure holes of import trade network do not directly affect innovation output.

Hypothesis 4: structure holes of import trade network play a positive moderating role in the function of innovation input on innovation output.

\section{EMPIRICAL ANALYSIS}

\subsection{Sample Description}

The research span of this paper is 2009-2015 years after the financial crisis. The data of international trade between EU member states are from the United Nations Database for trade in goods (UNCOMTRADE). In order to facilitate the analysis and statistics of the data, this paper standardized the processing of trade data. The purpose of data normalization is to eliminate dimension and eventually to make the data fall into a small specific interval. The specific formula model is as follows:

$$
X=\frac{X-M I N}{M A X-M I N}
$$

Where MAX is the maximum value of the sample data, MIN is the minimum value of sample data. The resulting data matrix is called a weighted network, $A_{i j}$ represent import value of country i to country $j$, so there is no sense of the value on the diagonal, which is defined as 0 .

The data of innovation input and innovation output comes from the global intellectual property organization (GII) issued by the International Intellectual Property Organization (WIPO), the European Institute of business administration, and Cornell University. The index was first published in 2007, and has been released 9 annual report. The global innovation index has modified in 2012. In view of the comprehensiveness and authority of the index, the global innovation index has become the main reference index for domestic and foreign scholars to study the national innovation capability. 


\subsection{Variable Measure}

\subsubsection{Dependent Variable}

The innovation output index in GII is used to measure innovation output, and the global innovation

Table 1: Composition of the Innovation Output Index (GII)

\begin{tabular}{|c|c|c|}
\hline $\begin{array}{l}\text { First level } \\
\text { index }\end{array}$ & $\begin{array}{l}\text { Second } \\
\text { level index }\end{array}$ & Third level index \\
\hline \multirow{3}{*}{$\begin{array}{l}\text { Knowledge } \\
\text { and } \\
\text { technology } \\
\text { outputs }\end{array}$} & $\begin{array}{l}\text { Knowledge } \\
\text { creation }\end{array}$ & $\begin{array}{l}\text { Patent applications by origin; PCT international applications by origin; Utility } \\
\text { model applications by origin; Scientific and technical publications; Citable } \\
\text { documents H index }\end{array}$ \\
\hline & $\begin{array}{l}\text { Knowledge } \\
\text { impact }\end{array}$ & $\begin{array}{l}\text { Growth rate of GDP per person engaged; New business density; Total computer } \\
\text { software spending; ISO } 9001 \text { quality certificates; High-tech and medium high- } \\
\text { tech output }\end{array}$ \\
\hline & $\begin{array}{l}\text { Knowledge } \\
\text { diffusion }\end{array}$ & $\begin{array}{l}\text { Intellectual property receipts; High-tech exports; ICT services exports; Foreign } \\
\text { direct investment, net outflows }\end{array}$ \\
\hline \multirow{3}{*}{$\begin{array}{l}\text { Creative } \\
\text { outputs }\end{array}$} & $\begin{array}{l}\text { Intangible } \\
\text { assets }\end{array}$ & $\begin{array}{l}\text { Trademark application class count by origin; Industrial designs by origin; ICTs } \\
\text { and business model creation; ICTs and organizational model creation }\end{array}$ \\
\hline & $\begin{array}{l}\text { Creative } \\
\text { goods } \quad \& \\
\text { services }\end{array}$ & $\begin{array}{l}\text { Cultural and creative services exports; National feature films produced, Global } \\
\text { entertainment and media market; Printing and publishing output; Creative goods } \\
\text { exports }\end{array}$ \\
\hline & $\begin{array}{l}\text { Online } \\
\text { creativity }\end{array}$ & $\begin{array}{l}\text { Generic top-level domains (gTLDs); Country-code top-level domains (ccTLDs); } \\
\text { Wikipedia yearly edits; Video uploads on YouTube }\end{array}$ \\
\hline
\end{tabular}

Source: Ithaca, Fontainebleau, Geneva, 2016. The Global Innovation Index: Winning with Global Innovation. Cornell University, INSEAD, and WIPO.

\subsubsection{Independent Variable}

Table 2: Composition of the Innovation Input Index (GII)

\begin{tabular}{|c|c|c|}
\hline $\begin{array}{ll}\begin{array}{l}\text { First } \\
\text { index }\end{array} & \text { level } \\
\end{array}$ & $\begin{array}{l}\text { Second level } \\
\text { index }\end{array}$ & Third level index \\
\hline \multirow{3}{*}{ Institutions } & $\begin{array}{l}\text { Political } \\
\text { environment }\end{array}$ & Political stability and absence of violence/terrorism; Government effectiveness \\
\hline & $\begin{array}{l}\text { Regulatory } \\
\text { environment }\end{array}$ & Regulatory quality; Rule of law; Cost of redundancy dismissal \\
\hline & $\begin{array}{l}\text { Business } \\
\text { environment }\end{array}$ & Ease of starting a business; Ease of resolving insolvency; Ease of paying taxes \\
\hline \multirow{3}{*}{$\begin{array}{l}\text { Human capital } \\
\text { and research }\end{array}$} & Education & $\begin{array}{l}\text { Expenditure on education; Government expenditure on education per pupil, } \\
\text { secondary; School life expectancy; Assessment in reading, mathematics, and } \\
\text { science; Pupil-teacher ratio, secondary }\end{array}$ \\
\hline & Tertiary education & $\begin{array}{l}\text { Tertiary enrolment; Graduates in science and engineering; Tertiary level inbound } \\
\text { mobility }\end{array}$ \\
\hline & $(\mathrm{R} \& \mathrm{D})$ & $\begin{array}{l}\text { Researchers; Gross expenditure on R\&D (GERD); Global R\&D companies, } \\
\text { average expenditure top 3; QS university ranking average score top } 3 \text { universities }\end{array}$ \\
\hline \multirow{3}{*}{ Infrastructure } & (ICTs) & ICT access; ICT use; Government’s online service; Online e-participation \\
\hline & $\begin{array}{l}\text { General } \\
\text { infrastructure }\end{array}$ & Electricity output; Logistics performance; Gross capital formation \\
\hline & $\begin{array}{l}\text { Ecological } \\
\text { sustainability }\end{array}$ & $\begin{array}{l}\text { GDP per unit of energy use; Environmental performance; ISO } 14001 \text { environmental } \\
\text { certificates }\end{array}$ \\
\hline \multirow{3}{*}{$\begin{array}{l}\text { Market } \\
\text { sophistication }\end{array}$} & Credit & $\begin{array}{l}\text { Ease of getting credit; Domestic credit to private sector; Microfinance institutions' } \\
\text { gross loan portfolio }\end{array}$ \\
\hline & Investment & Ease of protecting minority investors; Market capitalization; Venture capital deals \\
\hline & $\begin{array}{l}\text { Trade,competition } \\
\text {, \& market scale }\end{array}$ & $\begin{array}{l}\text { Applied tariff rate, weighted mean; Intensity of local competition; Domestic market } \\
\text { scale }\end{array}$ \\
\hline \multirow{3}{*}{$\begin{array}{l}\text { Business } \\
\text { sophistication }\end{array}$} & $\begin{array}{l}\text { Knowledge } \\
\text { workers }\end{array}$ & $\begin{array}{l}\text { Employment in knowledge-intensive services; Firms offering formal training; } \\
\text { GERD performed by business enterprise; GERD financed by business enterprise; } \\
\text { Females employed with advanced degrees }\end{array}$ \\
\hline & $\begin{array}{l}\text { Innovation } \\
\text { linkages }\end{array}$ & $\begin{array}{l}\text { University/industry research collaboration; State of cluster development; GERD } \\
\text { financed by abroad; Joint venture/strategic alliance deals; Patent families filed in at } \\
\text { least two offices }\end{array}$ \\
\hline & $\begin{array}{l}\text { Knowledge } \\
\text { absorption }\end{array}$ & $\begin{array}{l}\text { Intellectual property payments; High-tech imports; ICT services imports; Foreign } \\
\text { direct investment, net inflows; Research talent in business enterprise }\end{array}$ \\
\hline
\end{tabular}

Source: Ithaca, Fontainebleau, Geneva, 2016. The Global Innovation Index: Winning with Global Innovation.Cornell University, INSEAD, and WIPO. 
(1) Centrality. In this study, the initial data is a directed network of trade. According to direction the linkages are divided into out-degree and in-degree, because of concerning the effect of import trade network pattern of EU member states on the function of innovation output on innovation input, so this study only considers the index of in-degree. The numerical calculation can be obtained by UCINET (Jun Liu, 2016).

(2) Structural hole. There are two kinds of calculation indexes for structural holes, one is Burt's structural hole index (Burt, 1992), and the other is betweenness centrality index (Freeman, 1979; Brandes, 2008; Everett \& Borgatti, 2005). This paper uses Burt's structural hole index, which has four indicators: effective size, efficiency, constraints and hierarchy, of which the third indicators are most important. In order to facilitate the study, this paper uses the 1 minus limit as a measure of the capacity of a country to occupy the structure holes, and its data can be calculated by UCINET.
(3) Interactive items. To measure the effect of import trade pattern in the function of innovation input on innovation output, this paper introduces two interactive items, namely the trade network centrality multiplied by the innovation input and trade network structure holes multiplied by the innovation input. If the estimated coefficient of the interaction term is positive, the center centrality and (or) structural holes play a positive regulatory role in the function of innovation input on innovation output, and vice versa.

(4) Innovation input. This study uses the innovation input index of GII to measure innovation input, and the index is shown in the table 2 .

\subsection{Model Design}

\subsubsection{Unit Root Test of Total Sample}

In order to avoid the pseudo regression caused by non-stationary time series, the unit root test of the stationarity of the time series is first carried out. The test results are shown in table 3.

Table 3: Unit Root Test of Total Sample

\begin{tabular}{l|l|l|l|l}
\hline & $\begin{array}{l}\text { Levin, Lin \& } \\
\text { Chut }\end{array}$ & $\begin{array}{l}\text { Im, Pesaran and } \\
\text { Shin W-stat }\end{array}$ & ADF & PP \\
\hline Innovation input & $0.0000^{*}$ & $0.0000^{*}$ & $0.0000^{*}$ & $0.0000^{*}$ \\
\hline Trade network centrality & $0.9582^{*} / 0.0000^{* *}$ & $0.9995^{*} / 0.0007^{* *}$ & $\begin{array}{l}0.9958^{*} / 0.0010 \\
* *\end{array}$ & $0.8879 * / 0.0000^{* *}$ \\
\hline $\begin{array}{l}\text { Trade network structure hole } \\
\begin{array}{l}\text { Trade network centrality } \\
\text { multiplied by innovation inputs }\end{array}\end{array}$ & $0.1035^{*} / 0.0000^{* *}$ & $0.7720 * / 0.0008^{* *}$ & $\begin{array}{l}0.9645^{*} / 0.0240 \\
* *\end{array}$ & $0.1486 / 0.0018^{* *}$ \\
\hline $\begin{array}{l}\text { Trade network structure holes } \\
\text { multiplied by innovation inputs }\end{array}$ & $0.0000^{*}$ & $0.0037^{*}$ & $0.0101^{*}$ & $0.0000^{*}$ \\
\hline Innovation output & $0.0000^{*}$ & $0.00019^{*}$ & $0.0000^{*}$ & $0.0000^{*}$ \\
\hline
\end{tabular}

Notes: $*$ on behalf of the $\mathrm{p}$ value of original sequence of unit root test, $* *$ on behalf of the $\mathrm{p}$ value of a differential sequence of unit root test. Test type includes constant, not including the time trend, and lag order is determined by the SIC criterion.

\subsubsection{Co-integration Test of Total Sample}

In order to test whether the long-term co-integration relationship exists between variables, this study makes co-integration test using the common method, i.e. Pedroni test and Kao test, and the Pedroni test types including constant, not including the time trend, and the lag order is determined by the SIC criterion. The test results are shown in table 4 .

It can be seen from the table that the original hypothesis is rejected at the level of $1 \%$, and the Kao test also rejected the original hypothesis at a significance level of $5 \%$. The results show that there is a long-term co-integration relationship for each variable sequence.

Table 4: Co-integration Test of Total Sample

\begin{tabular}{|c|c|c|c|c|c|}
\hline Test method & Kao test & Pedroni & & & \\
\hline Statistic name & $\mathrm{ADF}$ & $\begin{array}{l}\text { Panel } \\
\text { ADF }\end{array}$ & Panel PP & Group ADF & Group PP \\
\hline Include intercept & \multirow{3}{*}{0.0373} & 0.0000 & 0.0000 & 0.0005 & 0.0000 \\
\hline Include intercept and trend & & 0.0000 & 0.9576 & 0.0000 & 0.0047 \\
\hline $\begin{array}{l}\text { Not include intercept and } \\
\text { trend }\end{array}$ & & 0.0000 & 0.0000 & 0.0000 & 0.0000 \\
\hline
\end{tabular}

Notes: * means significant in the level of $5 \%$, and ** means significant the level of $1 \%$.

\subsubsection{Model Selection and Test}

According to whether the constant term and the coefficient vector is constant, the panel data model can be divided into 3 types: mixed regression model (for constant), (coefficient is constant) and varying coefficient model (non for constant).

mixed regression mode:

$$
y_{i t}=\alpha+x_{i t} \beta+\mu_{i t} \quad i=1,2, \cdots, N ; t=1,2, \cdots, T
$$

variable intercept model:

$$
y_{i t}=\alpha_{i}+x_{i t} \beta+\mu_{i t} \quad i=1,2, \cdots, N ; t=1,2, \cdots, T
$$

variable coefficient mode:

$$
y_{i t}=\alpha_{i}+x_{i t} \beta_{i}+\mu_{i t} \quad i=1,2, \cdots, N ; t=1,2, \cdots, T
$$

To determine which model a panel data belongs to, $\mathrm{F}$ statistic can be used in this study:

$$
F_{1}=\frac{\left(S_{2}-S_{1}\right) /[(N-1) K]}{S_{1} /[N T-N(K+1)]} \sim F[(N-1) K, N(T-K-1)]
$$




$$
F_{2}=\frac{\left(S_{3}-S_{1}\right) /[(N-1)(K+1)]}{S_{1} /[N T-N(K+1)]} \sim F[(N-1)(K+1), N(T-K-1)]
$$

To test the following two hypotheses:

$$
\begin{aligned}
& H 1: \beta_{1}=\beta_{2}=\cdots=\beta_{N} \\
& H 2: \alpha_{1}=\alpha_{2}=\cdots=\alpha_{N}, \beta_{1}=\beta_{2}=\cdots=\beta_{N}
\end{aligned}
$$

Through the calculation of data, the most suitable model is mixed regression model. Since the number of cross sections is greater than the number of time series, the weights are weighted by section, which allows the existence of Heteroscedasticity in different sections. The

\begin{tabular}{|c|c|c|c|c|c|c|}
\hline & Model 1 & Model 2 & Model 3 & Model 4 & Model 5 & Model 6 \\
\hline Innovation input & $\begin{array}{l}0.938825 \\
(0.029517)\end{array}$ & $\begin{array}{l}0.969162 \\
(0.047087)\end{array}$ & $\begin{array}{l}0.975189 \\
(0.046862)\end{array}$ & $\begin{array}{l}0.969231 \\
(0.04687)\end{array}$ & $\begin{array}{l}0.890318 \\
(0.030935)\end{array}$ & $\begin{array}{l}1.124887 \\
(0.0938)\end{array}$ \\
\hline $\begin{array}{l}\text { Differential of import trade } \\
\text { network structure hole grade }\end{array}$ & & & $\begin{array}{l}24.23465 \\
(15.32603)\end{array}$ & $\begin{array}{l}23.42814 \\
(15.2801)\end{array}$ & & \\
\hline $\begin{array}{l}\text { Trade network structure holes } \\
\text { multiplied by innovation inputs }\end{array}$ & & & & & & $\begin{array}{l}0.156789 \\
(0.0949)\end{array}$ \\
\hline Constant & $\begin{array}{l}-9.075358 \\
(1.836081)\end{array}$ & $\begin{array}{l}-10.21872 \\
(2.649779)\end{array}$ & $\begin{array}{l}-10.51590 \\
(2.638569)\end{array}$ & $\begin{array}{l}-10.2052 \\
(2.63770)\end{array}$ & $\begin{array}{l}-7.115566 \\
(1.834646)\end{array}$ & $\begin{array}{l}-11.9736 \\
(2.7752)\end{array}$ \\
\hline Constant & $\begin{array}{l}-4.942787 \\
{[0.0000]}\end{array}$ & $\begin{array}{l}-3.856442 \\
{[0.0002]}\end{array}$ & $\begin{array}{l}-3.985455 \\
{[0.0001]}\end{array}$ & $\begin{array}{l}-3.86897 \\
{[0.0002]}\end{array}$ & $\begin{array}{l}-3.878440 \\
{[0.0000]}\end{array}$ & $\begin{array}{l}-4.31441 \\
{[0.0000]}\end{array}$ \\
\hline Variable 1 & $\begin{array}{l}31.80613 \\
{[0.0000]}\end{array}$ & $\begin{array}{l}20.3324 \\
{[0.0001]}\end{array}$ & $\begin{array}{l}20.6621 \\
{[0.0000]}\end{array}$ & $\begin{array}{l}20.67803 \\
{[0.0000]}\end{array}$ & $\begin{array}{l}28.7824 \\
{[0.0000]}\end{array}$ & $\begin{array}{l}11.32149 \\
{[0.0000]}\end{array}$ \\
\hline Variable 2 & & $\begin{array}{l}1.493478 \\
{[0.1375]}\end{array}$ & & $\begin{array}{l}1.443248 \\
{[0.1511]}\end{array}$ & & \\
\hline Variable 3 & & & $\begin{array}{l}1.581273 \\
{[0.1160]}\end{array}$ & $\begin{array}{l}1.533244 \\
{[0.1274]}\end{array}$ & & \\
\hline Variable 4 & & & & & $\begin{array}{l}9.173514 \\
{[0.0000]}\end{array}$ & \\
\hline
\end{tabular}
results of the simulation are shown in Table 5.

Table 5: Results of Model Estimation

Notes: * means significant at the level of $1 \%, * *$ indicates significant at $5 \%$ level. The bracket values after the coefficients are standard errors, and the brackets in the F-test and the T- est are the respective significant degrees. Because the structural holes in Cyprus and Malta are 0, the two countries are removed in the simulation.

\subsubsection{Theoretical Finding}

From the results of model 1, it can be seen that the impact of innovation input on innovation output is obvious, and the revised coefficient can reach 0.82 . Model 2 and model 3 respectively added import trade network centrality degree differential and import trade network structure hole grade difference. Model 4 adds these two explanatory variables to the model simultaneously. From the results, the model 2, 3 and 4 of the correction coefficient of determination quickly dropped to 0.75 , and can not pass the T-test and F-test, furthermore. From the results of granger causality test, the differential of hole degree and centrality degree does not constitute the granger reason of innovation output, so in the end the two explanatory variables is removed from the model. Model 5 takes the network center of import trade multiplied by innovation input into account. According to the simulation results, the model 5 correction coefficient of determination is improved from 0.82 to 0.86 , passing the T-test and F-test, and the coefficient is positive.

In summary, it can be assumed that hypotheses 1,2 , 3 and 4 have been validated.

(1) The structure of import trade network does not directly affect innovation output. The $\mathrm{CH}$ model and the
$\mathrm{CHH}$ model are the basis for the study of technology spillovers through international trade, and the empirical analysis of relevant literature is based on this model (Peiyuan Xu, Weisheng Gao, 2010). The technology spillover through import is an important form of technology spillover, and it emphasizes that importing countries can obtain the product by reverse engineering and imitation of imported products (Keller, Wolfgang, 2004). Due to the uncertainty of technology spillover, human capital, trade structure, degree of opening conditions, the number and share of imports, import trade network pattern does not directly affect the importing country innovation output.

(2) Centrality of import trade network plays a positive moderating role in the function of innovation input on output. Centrality reflects the centrality of a country in the European Union's trade network, symbolizing the strong ties between a country and other countries. The higher the centrality, the more a country can integrate resources at a deeper and broader level, and innovation input can better promote the innovation output of a country through the resource integration ability.

(3) structure holes of import trade network play a positive moderating role in the function of innovation 
input on innovation output. Occupying the location of the structure holes, can obtain a large number of non redundant heterogeneous resources, and bring more trade advantage. So, this advantage further evolved into the country's social capital, and weakening effects of technology spillover in uncertainty.

\section{CONCLUSIONS}

In the perspective of social network, the conclusion of this article is that the import trade network pattern does not directly affect the output of innovation, but the import trade structure plays a positive regulatory role in function of innovation input affecting on innovation output. Import trade will influence the innovation output through technical spill over, but the capital goods and intermediate goods will directly improve the production efficiency as materializing technology, at the same time as the operation and use of machinery and equipment, technology and non-materialization of tacit knowledge has been transferred (Xu, Wang, 1999), However, in this paper, there is no classification of capital goods and noncapital goods. Secondly, there are many constraints on technology spillover through import trade, which include human capital, product structure, openness and so on. Therefore, the follow-up study of this paper can be extended from the following two aspects: (1) to investigate the role of capital goods and intermediate goods import trade pattern in the function of effect of innovation input on output; (2) to consider more constraints to the model.

\section{REFERENCES}

[1] Arrow, K.J., 1962. Economic welfare and the allocation of resources for invention. In the rate and direction of inventive activity: economic and social Factors nelson RR (Ed). Princeton University Press. Princeton.

[2] Brandes, U., 2008. On variants of shortest-path betweenness centrality and their generic computation. Social networks. 30(2), pp.136-145.

[3] Burt, R.S., 1992. Structural holes: the social structure of competition. Harvard University press. Cambridge.

[4] Coe, D.T., Helpman, E., 1995. International R\&D spillers, European economic reviews. 39, pp.859-887.

[5] Coe, D.T., Helpman, E. and Hoffinaister, W., Alexandar., 1997. North-South R\&D spillovers, Economic journal. 107, pp.134-149.
[6] Ithaca, Fontainebleau, Geneva, 2016. The global innovation index: winning with global innovation. Cornell University, INSEAD, and WIPO.

[7] Engelbrecht, Hans-Jeurgen, 1997. International R\&D spillovers, human capital and productivity in OECD economies: an empirical investigation, European economic Review. 08.

[8] Everett, M., Borgatti, S., 2005. Ego network betweenness. Social networks. pp.31-38.

[9] Findlay, R., 1978. Relative backwardness, direct Foreign investment technology: a simple dynamic model, Quarterly journal economics. 92, pp.1-16.

[10] Freeman, L.C., 1979. Centrality in social networks: conceptual clarification, Social networks. 1, pp.215-239.

[11] Gnyawali, D., Madhavan, R., 2001. Cooperative networks and competitive dynamics: a structural embeddedness perspective, Academy of management review.26 (3), pp.431445.

[12] Granovetter, M., 1973. The strength of weak ties, American journal of sociology. 78, pp.1287-1303.

[13] Grossman, G.M., Helpman, E., 1989. Growth and welfare in a small open economy, Social science electronic publishing.MA.

[14] Jun Liu, 2016. A practical guide to whole net analysis of UCINET software, Shanghai people's publishing house. Shanghai, 2nd. edition.

[15] Keller, Wolfgang, 2002. Trade and the transmission of technology, Journal of economic growth. 7(1), pp.5-24.

[16] Keller, Wolfgang, 2004. International technology diffusion, Journal of economic literature. 42(3), pp.752-782.

[17] Lucas, 1988. Economic development, Journal monetary economics. 22(1), pp.3-42.

[18] Peiyuan Xu, Weisheng Gao. 2010. International trade and technology spillover: a summary of empirical evidences. International economics and trade research. 26(51), pp.9-14.

[19] Romer, M., 1986. Increasing return long-run growth, Journal political economy. 94(5), pp.1002-1037.

[20] Schiff, M. Yanling, W. and Olarreaga, M., 2002. Traderelated technology diffusion and the dynamics of North-South and South-South integration, World Bank policy research working paper. No.2861.

[21] Sjoholm, Fredrik, 1996. Productivity growth in Indonesia: the role of regional characteristics and direct foreign investment, Development and cultural change. 47, pp.559-584.

[22] Xu B., Wang J., 1999. Capital goods trade and R\&D spillovers in the OECD, Canadian journal of economics. 32(5), pp.1258-1274.

[23] Zhenfu Li, Yu Miao, Jing Chen, 2017. Analysis on the economic circle trade work of arctic shipping routes based on structural holes' theory, Journal of central China normal university (Nat. Sci.). 51(1), pp.100-114.

[24] Zhiyong Zhang, Yi Liu, En Xie., 2007. Research on tacit knowledge transfer of R\&D team based on dynamic network model, Operations research and management science. (06), pp.142-147. 